\title{
Efektifitas Penegakan Hukum terhadap Pelaku Tindak Pidana Pembakaran Hutan di Provinsi Jambi
}

\author{
Reza Iswanto ${ }^{1}$, Sumaidi ${ }^{2}$ \\ ${ }^{1,2}$ Fakultas Hukum Universitas Batanghari \\ Jalan Slamet Riyadi Broni Kota Jambi Telp: (0741) 65351 \\ Corrrespondence email : rezaiswanto17@gmail.com
}

\begin{abstract}
Abstrak. Masalah pembakaran hutan sudah menjadi problem di Provinsi Jambi karena mengingat banyaknya asap yang ditimbulkan dari kebakaran hutan sehingga merugikan masyarakat Provinsi Jambi. Oleh karena itu, harus ada penegakan hukum terhadap pelaku yang melakukan pembakaran hutan sehingga pembakaran hutan itu tidak terjadi lagi. Namun, kenyataannya penegakan hukum juga masih ada tebang pilih sehingga kasus yang terungkap hanya melibatkan pelaku perorangan saja, sedangkan untuk perusahaan hanya satu perusahaan saja yang disegel. Selain itu juga, faktor yang mempengaruhi penegakan hukum itu sendiri seperti kurangnya kemampuan sumber daya manusia tentang pemahaman tindak pidana lingkungan, peralatan seadanya dan banyaknya pengaturan tentang alat bukti dalam undang-undang sehingga upaya kedepannya dalam melakukan penegakan hukum terhadap tindak pidana pembakaran hutan yaitu sumber daya manusia penegak hukumnya harus ditingkatkan, mempersiapkan peralatan yang canggih dan pembuktian tidak harus banyak alat bukti.
\end{abstract}

Kata Kunci: Efektifitas, Penegakan Hukum, Pembakaran Hutan.

\begin{abstract}
The problem of forest burning has become a problem in Jambi Province because it is considering the amount of smoke generated from forest fires that is detrimental to the people of Jambi Province. Therefore, there must be law enforcement against those who carry out forest fires so that forest fires do not happen again. However, in reality law enforcement also still has selective logging so that the cases revealed only involve individual actors, whereas for companies only one company is sealed. In addition, factors affecting law enforcement itself such as the lack of human resource capacity regarding understanding of environmental crime, improper equipment and the many regulations regarding evidence in the law so that future efforts in carrying out law enforcement against forest fires are resource human law enforcement must be improved, prepare sophisticated equipment and proof does not have a lot of evidence.
\end{abstract}

Keywords: Effectiveness, Law Enforcement, Forest Burning.

\section{PENDAHULUAN}

Hutan sangat berperan penting dalam kehidupan makhluk hidup terutama terhadap manusia sehingga kelestarian hutan harus dijaga demi keberlangsungan makhluk hidup yang hidup di dunia. Bayangkan saja jika hutan tidak lagi dilestarikan maka akan banyak timbul permasalahan terhadap makhluk hidup seperti terjadinya kebanjiran karena tidak ada lagi pohon-pohon yang ada di hutan untuk meresap air. Tidak hanya itu saja, yang lebih membahayakan lagi jika hutan tidak dilestarikan maka kadar oksigen untuk manusia akan menjadi berkurang sehingga manusia akan mengalami berbagai macam penyakit terkait dengan pernapasan seperti penyakit paru-paru, jatung dan sesak nafas. Hal yang demikian tidak menutup kemungkinan manusia itu sendiri akan mengalami kematian akibat kabut asap tebal yang hasil dari pembakaran hutan tersebut.

Untuk itu, perlu dilakukan penegakan hukum terhadap tindak pidana pembakaran hutan sehingga hutan dapat berfungsi sebagaimana mestinya yaitu dapat menghasilkan oksigen karena oksigen tersebut dapat berguna untuk makhluk hidup terutama manusia. Akan tetapi, pada kenyataannya masih banyak perusahaan dalam menjalankan aktivitas usahanya guna untuk memperkecil anggaran dalam membuka lahan maka perusahaan melakukan pembakaran hutan sehingga akibat dari pembakaran hutan tersebut sangat membahayakan masyarakat Provinsi Jambi. Hal ini dapat dibuktikan dengan adanya berita dari Liputan6.com, Jambi yang pada intinya adalah Kualitas udara jika dibandingkan pada tahun 2015 maka lebih buruk karena disebabkan oleh kabut asap yang berasal dari kebakaran hutan dan lahan yang terjadi di Provinsi Jambi. Apabila dilihat dari data yang diberitakan oleh Badan Meteorologi, Klimatologi dan Geofisika (BMKG) yang menyatakan bahwa Indeks Standar Pencemaran Udara (ISPU) telah mencapai angka 411 gram per meter kubik. Ini artinya, partikel polutan yang dihasilkan dari kabut asap kebakaran hutan dan lahan tersebut telah masuk pada level berbahaya. ${ }^{1}$

Mengingat hal yang demikian tentunya sangat disayangkan karena pelaku pembakaran hutan terutama perusahaan sudah seharusnya dijerat sanksi pidana karena akibat perbuatan perusahaan yang melakukan pembakaran

1 https://www.liputan6.com/health/read/4070445/kualitas-udara-jambi-akibat-kabut-asap-saat-ini-lebih-buruk-dari-2015, diakses tanggal 10 Oktober 2019. 
hutan tersebut dapat mengakibatkan kerugian yang cukup besar sebab dalam kasus pembakaran hutan itu tidak hanya manusia saja yang dirugikan melainkan flora dan fauna juga ikut punah akibat kebakaran hutan. akan tetapi, pada kenyataannya pelaku tindak pidana yaitu perusahaan yang telah melakukan tindak pidana pembakaran hutan untuk saat ini masih belum ada penjeratan sanksi pidana oleh penegak hukum. Hal yang demikian dapat dibuktikan dengan adanya pernyataan dari CNN Indonesia yang pada intinya menjelaskan bahwa di Provinsi Jambi hanya dilakukan penyegelan terhadap satu perusahaan perkebunan saja oleh Kementerian Lingkungan Hidup dan Kehutanan. Perusahaan perkebunan itu terletak di daerah Kabupaten Muaro Jambi. ${ }^{2}$

Apabila dilihat dari kasus tersebut maka penjeratan terhadap perusahaan yang telah melakukan pembakaran hutan hanya dijerat dengan sanksi administratif saja. Adapun sanksi administratif dalam kasus ini adalah Kementerian Lingkungan Hidup dan Kehutanan melakukan penyegelan terhadap perusahaan tersebut. Apabila melihat sanksi pidana terhadap pelaku pelaku tindak pidana pembakaran hutan telah diatur di dalam Pasal 108 Undang-Undang Nomor 32 Tahun 2009 Tentang Perlindungan Dan Pengelolaan Lingkungan Hidup. Adapun inti dalam pasal tersebut yaitu setiap yang melakukan pembakaran hutan dijerat dengan pidana penjara paling singkat 3 tahun dan paling lama 10 tahun dengan denda paling sedikit Rp. 3.000.000.000,00 (tiga miliar rupiah) dan paling banyak Rp10.000.000.000,00 (sepuluh miliar rupiah). Adanya pengaturan di dalam pasal ini bertujuan untuk meminimalisir tingkat tindak pidana kebakaran hutan di Provinsi Jambi sehingga dengan keadaan yang demikian maka masyarakat Provinsi Jambi dapat menghirup udara segar kembali.

Namun, sampai saat ini sanksi pidana yang terdapat dalam Pasal 108 di atas belum dijerat terhadap pelaku tindak pidana pembakaran hutan khusunya terhadap perusahaan. Padahal apabila mengacu pada legalitas sebagaimana yang tercantum di dalam Pasal 1 ayat (1) Kitab Undang-Undang Hukum Pidana (KUHP) yang pada intinya menjelaskan bahwa harus ada terlebih dahulu suatu perbuatan yang dapat dijerat dengan sanksi pidana, kecuali perbuatan tersebut belum diatur di dalam undang-undang sehingga tidak dapat dijerat dengan sanksi pidana. Jadi, harus ada undang-undang terlebih dahulu mengatur terkait dengan suatu tindak pidana, baru perbuatan tersebut dapat dikatakan tindak pidana. Jika perbuatan tersebut belum ada undang-undang yang mengaturnya maka perbuatan itu tidak dapat dikatakan tindak pidana. Rumusan di dalam pasal ini menyatakan bahwa dapat dipidananya seseorang atas suatu tindak pidana yang dilakukannya dan tindak pidana tersebut harus secara tertulis diatur di dalam hukum pidana materiil. $^{3}$

Tindak pidana pembakaran hutan ini sebenarnya sudah diatur dalam Pasal Pasal 69 ayat (1) huruf h UndangUndang Nomor 32 Tahun 2009 Tentang Perlindungan Dan Pengelolaan Lingkungan Hidup. Di dalam pasal tersebut menyatakan bahwa melakukan pembukaan hutan dengan cara membakar. Ini artinya, Di dalam melakukan pembukaan hutan baik itu orang maupun perusahaan melakukan pembukaan hutan tersebut dengan cara membakar hutan itu. Untuk itu, sudah seharusnya bagi penegak hukum untuk menegakkan pasal tersebut terhadap pelaku tindak pidana pembakaran hutan di Provinsi Jambi karena untuk apa suatu aturan hukum dibuat kalau tidak dijalankan dan dipatuhi oleh penegak hukum. Dengan tidak dijalankan pasal dalam undang-undang tersebut oleh penegak hukum maka tidak menutup kemungkinan kedepannya pelaku perusahaan akan lebih memperluas pembakaran hutan untuk membuka lapangan usahanya sebab belum ada perusahaan yang dijatuhkan sanksi pidana.

Ini berati membuktikan bahwa penegakan hukum terhadap pelaku pembakaran hutan masih dirasakan belum efektif karena para pelaku pembakaran hutan yang terjerat dengan sanksi pidana belum ada, bahkan masih ada perusahaan yang menjadi pelaku pembakaran hutan masih tetap beroperasi dalam menjalankan perusahaannya. Jika hal ini terus terjadi maka dikhawatirkan kedepannya akan menimbulkan banyak lagi kadar asap di Provinsi Jambi. Sedangkan tujuan dari adanya undang-undang terkait dengan lingkungan hidup ini adalah melindungi makhluk hidup secara umum agar mereka dapat berkembang biak di alam bebas dan pada khususnya pada manusia untuk melangsungkan hidup agar terhindar dari pencemaran dan kerusakan lingkungan hidup yang akan mengamcam kelangsungan hidup semua makhluk hidup.

Abdoel Djamali juga menjelaskan pada umumnya tujuan hukum pidana yaitu aturan hukum yang mengatur terkait pembatasan tingkah laku pada manusia untuk tidak melakukan pelanggaran terhadap kepentingan umum sehingga hak setiap makhluk hidup khususnya manusia tidak dilanggar pelaku tindak pidana, termasuk pelaku tindak pidana pembakaran hutan. ${ }^{4} \mathrm{Jadi}$, jika dilihat dari tujuan undang-undang tersebut selain untuk melindungi kelangsungan kehidupan makhluk hidup, tujuan undang-undang itu sendiri juga untuk membatasi perbuatan-perbuatan yang melakukan pencemaran lingkungan sehingga kedepannya tidak ada lagi perbuatan yang melakukan pencemaran lingkungan tersebut seperti dalam hal ini yaitu perbuatan pembakaran hutan.

Sementara itu, di ketahui bahwa kadar asap yang dikeluarkan dari hasil pembakaran hutan itu sangat banyak merugikan masyarakat seperti gangguan pernapasan, anak-anak sekolah harus diliburkan demi terlindunginya

2 https://www.cnnindonesia.com/nasional/20190821080552-20-423248/satu-perusahaan-perkebunan-di-jambi-disegelakibat-karhutla, diakses tanggal 10 Oktober 2019.

${ }^{3}$ Roni Wiyanto, Asas-Asas Hukum Pidana Indonesia, (Bandung : CV. Mandar Maju, 2012), halaman 67.

${ }^{4}$ Abdoel Djamali, Pengantar Hukum Indonesia, (Jakarta : Rajawali Pers, 2014), halaman 173. 
pernapasan anak-anak tersebut dari asap, pengendara sepeda motor dan mobil mengalami gangguan penglihatan karena tebalnya kabut asap yang menutupi jalan serta yang paling merugikan manusia dalam hal kabut asap tersebut yaitu bagi penumpang penerbangan pesawat yang ingin terbang ke suatu Provinsi akan mengalami penundaan penerbangan dikarenakan kabut asap yang membuat pesawat terbang tersebut tidak dapat terbang dikarenakan menutupi penglihatan pilot dalam hal penerbangan.

Dengan adanya permasalahan tersebut maka sudah seharusnya dilakukan penegakan hukum secara tegas terhadap pelaku tindak pidana pembakaran hutan khususnya terhadap perusahaan sehingga pembakaran hutan untuk kedepannya dapat diminimalisir bahkan kalau perlu tidak ada lagi pembakaran hutan di Provinsi Jambi. Untuk itu, penulis memberikan batasan terkait dengan permasalahan yang akan di bahas dalam makalah ini. Adapun batasan masalah terkait dengan permasalan di atas yaitu :

1. Bagaimana efektivitas penegakan hukum terhadap pelaku tindak pidana pembakaran hutan di Provinsi Jambi ?

2. Faktor-faktor apa saja yang mempengaruhi penegakan hukum terhadap pelaku tindak pidana pembakaran hutan di Provinsi Jambi?

3. Bagaimana upaya yang akan datang terkait dengan penegakan hukum terhadap pelaku tindak pidana pembakaran hutan di Provinsi Jambi?

\section{METODE PENELITIAN}

Di dalam melakukan suatu penelitian tentunya dibutuhkan suatu metode penelitian untuk mempermudah penulis dalam mengkaji objek yang ditelitinya. Hal yang demikian juga senada dengan pendapat Ishaq yang menyatakan bahwa metode adalah cara melakukan sesuatu penelitian menurut aturan yang telah diberlakukan khusus. ${ }^{5}$ Oleh karena itu, penulis akan menguraikan susunan metode penelitian untuk mempermudah dalam memahami permasalahan yang sedang diteliti. Adapun metode penelitian yang digunakan dalam hal ini yaitu:

\section{Metode pendekatan}

Sebelum penulis menjelaskan terkait dengan metode pendekatan dalam penelitian ini, terlebih dahulu penulis akan memberitahukan bahwa tipe penelitian dalam makalah ini yaitu penelitian empiris. Metode penelitian empiris merupakan penelitian hukum yang mengkaji fakta-fakta yang terjadi di lapangan melalui objek penelitiannya berupa sikap dan perilaku sosial terhadap hukum yang berlaku. ${ }^{6}$ Oleh karena itu, di dalam penelitian ini terlebih dahulu melihat aturan hukum terkait dengan tindak pidana membakar hutan yaitu Undang-Undang Nomor 32 Tahun 2009 Tentang Perlindungan Dan Pengelolaan Lingkungan Hidup, kemudian meneliti keefektivitasan penegakan UndangUndang Nomor 32 Tahun 2009 Tentang Perlindungan Dan Pengelolaan Lingkungan Hidup yang dilakukan oleh penegak hukum tersebut terhadap pelaku tindak pidana pembakaran hutan di provinsi Jambi. Dengan demikian, objek penelitian di dalam penelitian ini adalah sikap dan perilaku penegak hukum dalam menegakkan Undang-Undang Nomor 32 Tahun 2009 Tentang Perlindungan Dan Pengelolaan Lingkungan Hidup di dalam masyarakat Provinsi Jambi.

Selanjutnya, apabila dilihat dari tipe penelitian yang telah dijelaskan di atas maka metode pendekatan dalam penelitian ini adalah sosiologi hukum. Hal yang demikian juga diutarakan oleh Ishaq bahwa pendekatan dan sering digunakan dalam penelitian hukum empiris mencakup pada $:^{7}$

a. Pendekatan sosiologi hukum.

b. Pendekatan antropologi hukum.

c. Pendekatan psikologi hukum.

Adapun karakter sosiologi hukum pada umumnya ialah menganalisis tentang penerapan undang-undang yang dijalankan oleh badan Insan atau penegak hukum sehingga memberikan gambaran secara umum terkait dengan undang-undang tersebut sesuai atau tidak untuk diterapkan di dalam kehidupan masyarakat tersebut serta memberikan penilaian bagaimana terkait dengan bagaimana seharusnya hukum tersebut terjadi di dalam masyarakat sehingga hukum itu dapat dipatuhi oleh masyarakat tersebut. ${ }^{8}$ Diadakan pendekatan sosiologi hukum di dalam penelitian ini disebabkan karena penulis akan menganalisis terlebih dahulu sejauh mana undang-undang tersebut telah diterapkan oleh penegak hukum terhadap pelaku tindak pidana pembakaran hutan yang selama ini terjadi di di Provinsi Jambi.

Selain itu juga, melihat apa yang seharusnya diperbaiki untuk kedepannya dalam penegakan Undang-Undang Nomor 32 Tahun 2009 Tentang Perlindungan Dan Pengelolaan Lingkungan Hidup sehingga Undang-Undang Nomor 32 Tahun 2009 Tentang Perlindungan Dan Pengelolaan Lingkungan Hidup itu sendiri dapat diterapkan di dalam masyarakat Provinsi Jambi.

\footnotetext{
${ }^{5}$ Ishaq, Metode Penelitian Hukum, (Bandung : Alfabeta, 2017), halaman 25.

${ }^{6}$ I Made Pasek Diantha, Metode Penelitian Hukum Normatif Dalam Justifikasi Teori Hukum, (Jakarta : Prenada Media
} Group, 2016), halaman 12.

${ }^{7}$ Ishaq, Op.Cit, halaman 71.

${ }^{8}$ Yesmil Anwar dan Adang, Pengantar Sosiologi Hukum, (Jakarta: PT. Grasindo, 2007), halaman 113. 


\section{Rancangan kegiatan}

Di dalam penelitian hukum empiris ini dilakukan rancangan kegiatan agar mendapat hasil yang diteliti sesuai dengan yang diharapkan. Rancangan kegiatan ini dilakukan guna untuk mempercepat dan mempermudah penulis dalam melakukan penelusuran terkait dengan kasus tindak pidana pembakaran hutan yang terjadi di Provinsi Jambi. Hal yang demikian ini juga diutarakan oleh Kansel bahwa sosiologi hukum bukan dalam rangka mengkaji norma keharusan itu sendiri, tetapi untuk menjelaskan peranan dan perilaku subjek hukum dalam memunculkan atau mengapa norma itu cenderung dilanggar oleh subjek hukum sehingga tidak efektif dan tidak manjur. ${ }^{9}$

Untuk itu, apabila dilihat dalam penelitian ini yang mana menggunakan pendekatan sosiologi hukum maka rancangan kegiatan yang dilakukan di dalam penelitian ini adalah langsung menganalisis penerapan Undang-Undang Nomor 32 Tahun 2009 Tentang Perlindungan Dan Pengelolaan Lingkungan Hidup yang terjadi di masyarakat Provinsi Jambi terkait dengan tindak pidana pembakaran hutan di Provinsi Jambi dan mengapa Undang-Undang Nomor 32 Tahun 2009 Tentang Perlindungan Dan Pengelolaan Lingkungan Hidup itu tidak diterapkan sepenuhnya oleh aparat penegak hukum terhadap pelaku tindak pidana pembakaran hutan di Provinsi Jambi.

\section{Ruang lingkup atau objek}

Diadakan ruang lingkup dalam penelitian ini bertujuan agar ada batasan yang dikaji di dalam penelitian ini sehingga memfokuskan bagi peneliti untuk meneliti permasalahan yang sedang diteliti dan mempermudah bagi pembaca untuk memahami permasalahan yang sedang diteliti oleh peneliti. Adapun ruang lingkup di dalam penelitian ini adalah Undang-Undang Nomor 32 Tahun 2009 Tentang Perlindungan Dan Pengelolaan Lingkungan Hidup dan peran penegak hukum. Kemudian objek kajian penelitian hukum empiris menurut Peter Mahmud Marzuki adalah sebagai berikut : ${ }^{10}$

a. Efektivitas aturan hukum.

b. Kepatuhan terhadap aturan hukum.

c. Peranan lembaga atau instansi hukum dalam penegakan hukum.

d. Implementasi aturan hukum.

e. Pengaruh aturan hukum terhadap masalah sosial tertentu atau sebaliknya.

f. pengaruh masalah sosial tertentu terhadap aturan hukum.

Selain itu juga, efektivitas penegak hukum merupakan peran penegak hukum di dalam memantau situasi dan kondisi sehingga menjadi kondusif dan tidak terjadi pelanggaran lagi. Hal ini dikatakan demikian karena pada dasarnya efektivitas adalah tingkat pencapaian dan keberhasilan dari suatu tujuan. Apabila dikaitkan dengan efektivitas penegak hukum maka dikatakan efektivitas di dalam penegakan hukum harus tercapai suatu tujuan dan keberhasilan di dalam melindungi dan mengayomi masyarakat dari berbagai macam bahaya.

Dengan demikian, sudah jelas bahwa di dalam penelitian ini terlebih dahulu melihat isi Undang-Undang Nomor 32 Tahun 2009 Tentang Perlindungan Dan Pengelolaan Lingkungan Hidup terkait dengan penjelasan sanksi pidana terhadap pelaku tindak pidana pembakaran hutan, kemudian melihat peran yang dilakukan oleh penegak hukum di dalam mengefektivitaskan Undang-Undang Nomor 32 Tahun 2009 Tentang Perlindungan Dan Pengelolaan Lingkungan Hidup di dalam masyarakat Provinsi Jambi.

\section{Bahan dan alat utama}

Bahan yang dimaksudkan dalam penelitian ini adalah bahan yang akan digunakan untuk mengkaji permasalahan yang sedang diangkat yaitu permasalahan tentang efektivitas Undang-Undang Nomor 32 Tahun 2009 Tentang Perlindungan Dan Pengelolaan Lingkungan Hidup yang dilakukan oleh aparat penegak hukum terhadap pelaku tindak pidana pembakaran hutan di Provinsi Jambi. Adapun bahan yang digunakan di dalam penelitian ini adalah data primer. Data primer yakni data yang diperoleh sumbernya langsung dari lapangan. ${ }^{11}$

Oleh karena itu, peneliti langsung melakukan pengamatan secara langsung di lapangan terkait dengan penjeratan sanksi pidana terhadap pelaku tindak pidana pembakaran hutan di Provinsi Jambi. Sedangkan alat utama yang digunakan di dalam penelitian ini adalah alat elektronik seperti handphone guna untuk mendapatkan informasi yang akurat dilapangan.

\section{Teknik pengumpulan data}

Di dalam penelitian hukum empiris ini digunakan data primer dan data sekunder untuk mempermudah penulis untuk menganalisa permasalahan yang sedang terjadi. Adapun data primer metode pengumpulan yang dilakukan dengan menggunakan observasi, wawancara dan kuesioner. ${ }^{12}$ Sedangkan data sekunder metode pengumpulan nya

\footnotetext{
${ }^{9}$ I Made Pasek Diantha, Op.Cit, halaman 99.

${ }^{10}$ Ishaq, Op.Cit, halaman 71.

11 Ibid.

${ }^{12} \mathrm{Ibid}$, halaman 73.
} 
dilakukan dengan cara membaca di perpustakaan atau literatur, pengutipan yang mempunyai hubungannya dengan permasalahan penelitian. ${ }^{13}$

Oleh karena itu, pengumpulan data primer dilakukan dengan cara langsung melakukan pengamatan di lapangan terkait dengan penjeratan sanksi pidana terhadap pelaku tindak pidana pembakaran hutan di Provinsi Jambi. Selain itu juga, menggunakan data sekunder dengan cara melakukan pengumpulan berbagai macam literature, baik itu buku maupun majalah atau koran yang berkaitan dengan tindak pidana pembakaran hutan.

\section{Teknik analisis}

Teknik analisis di dalam penelitian ini dengan cara kualitatif. Kualitatif yakni menguraikan data secara berkualitas dan komprehensif dalam bentuk kalimat yang teratur, logis, tidak tumpang tindih dan efektif sehingga memudahkan pemahaman dan interpretasi data. ${ }^{14}$ Untuk itu, di dalam penelitian ini teknik analisis digunakan dengan cara kualitatif yaitu dengan menguraikan data yang telah terhimpun baik itu dari lapangan maupun dari pustaka dalam bentuk kalimat atau narasi yang teratur, demi untuk mempermudah di dalam menjelaskan permasalahan yang sedang diteliti sehingga bagi pembaca dapat dengan mudah memahami pokok permasalahan yang sedang diteliti oleh penulis

\section{HASIL DAN PEMBAHASAN}

\section{Efektivitas Penegakan Hukum Terhadap Pelaku Tindak Pidana Pembakaran Hutan Di Provinsi Jambi}

Setiap aturan hukum yang dibuat oleh badan legislatif, selain sebagai pedoman untuk bertingkah laku terhadap manusia, aturan hukum tersebut juga berfungsi untuk membatasi tingkah laku manusia sehingga tidak melanggar kepentingan umum atau orang lain. Aturan hukum tersebut dapat berupa undang-undang, perpu, peraturan pemerintah bahkan sampai dengan peraturan desa. Akan tetapi, dalam hal hukum lingkungan telah ada aturan hukumnya yaitu Undang-Undang Nomor 32 Tahun 2009 Tentang Perlindungan Dan Pengelolaan Lingkungan Hidup.

Timbulnya Undang-Undang Nomor 32 Tahun 2009 Tentang Perlindungan Dan Pengelolaan Lingkungan Hidup ini karena sesuai dengan isi pasal 28 huruf H Undang-Undang Dasar Negara Republik Indonesia Tahun 1945 yang mengamanatkan bahwa lingkungan hidup yang baik dan sehat merupakan hak asasi setiap warga negara Indonesia. Oleh karena itu, apabila ada yang melanggar undang-undang tersebut maka sudah termasuk melanggar hak asasi setiap orang untuk sehat karena apabila undang-undang lingkungan hidup tersebut dilanggar tentunya akan merusak kelestarian alam dan pencemaran lingkunan sehingga mengakibatkan kerugian yang begitu besar terhadap masyarakat, flora dan fauna serta negara.

Untuk itu, selain dibutuhkan aturan hukum seperti Undang-Undang Nomor 32 Tahun 2009 Tentang Perlindungan Dan Pengelolaan Lingkungan Hidup dalam melestarikan lingkungan hidup, diperlukan juga penegakan terhadap undang-undang tersebut sehingga apabila terjadi permasalahan dilapangan seperti tindak pidana pembakaran hutan maka Undang-Undang Nomor 32 Tahun 2009 Tentang Perlindungan Dan Pengelolaan Lingkungan Hidup dapat digunakan oleh penegak hukum untuk menjerat pelaku tindak pidana pembakaran hutan sebab telah melanggar undang-undang tersebut.

Dengan demikian, dilihat dari eksistensi Undang-Undang Nomor 32 Tahun 2009 Tentang Perlindungan Dan Pengelolaan Lingkungan Hidup maka upaya penegakan hukum dilakukan dengan cara menggunakan sanksi pidana yang terdapat di dalam Undang-Undang Nomor 32 Tahun 2009 Tentang Perlindungan Dan Pengelolaan Lingkungan Hidup. Sanksi pidana tersebut merupakan upaya penal dalam melakukan penegakan hukum karena menurut Abintoro Prakoso upaya penanggulangan kejahatan lewat jalur penal lebih menitikberatkan pada sifat represif penindasan/pemberantasan/penumpasan sesudah kejahatan itu terjadi. ${ }^{15}$ Sedangkan tindakan represif adalah serangkaian tindakan yang dilakukan oleh petugas hukum melalui proses hukum pidana karena perbuatan yang dilakukan oleh pelaku merusak dan mencemari lingkungan. ${ }^{16} \mathrm{Jadi}$, apabila telah terjadi tindak pidana pembakaran hutan maka terhadap pelaku tindak pidana pembakaran hutan tersebut dapat dikenakan sanksi pidana sesuai dengan isi Pasal 108 yang tercantum di dalam Undang-Undang Nomor 32 Tahun 2009 Tentang Perlindungan Dan Pengelolaan Lingkungan Hidup guna untuk memberantas tindak pidana pembakaran hutan agar kedepannya tidak ada lagi pembakaran hutan.

Sebenarnya keberadaan sanksi ini dimaksudkan sebagai alat pemaksa atau penolong atau jaminan agar norma hukum pidana ditaati, juga sebagai akibat hukum bagi orang yang telah melanggar norma hukum pidana. ${ }^{17}$ Dengan adanya sanksi pidana yang terdapat dalam pasal 108 Undang-Undang Nomor 32 Tahun 2009 Tentang Perlindungan
${ }^{13}$ Ibid.
14 Ibid.
${ }^{15}$ Abintoro Prakoso, Kriminologi Dan Hukum Pidana, (Yogyakarta : Laksbang Grafika, 2013), halaman 159.
16 Masrudi Muchtar, Abdul Khair Dan Noraida, Hukum Kesehatan Lingkungan (Kajian Teoritis Dan Perkembangan Pemikiran), (Yogyakarta : Pustaka Baru Press, 2016), halaman 122.
${ }^{17}$ Nandang Sambas dan Ade Mahmud, Perkembangan Hukum Pidana Dan Asas-Asas Dalam RKUHP, (Bandung : PT. Refika Aditama, 2019), halaman 7. 
Dan Pengelolaan Lingkungan Hidup tersebut selain merupakan alat pemaksa untuk menjerat pelaku tindak pidana pembakaran hutan akibat dari perbuatannya melakukan pembakaran hutan, sanksi pidana tersebut juga menjamin agar Undang-Undang Nomor 32 Tahun 2009 Tentang Perlindungan Dan Pengelolaan Lingkungan Hidup ditaati oleh setiap orang sehingga tindak pidana pembakaran hutan tidak akan terjadi kembali.

Namun, walaupun sanksi pidana telah diatur dalam Undang-Undang Nomor 32 Tahun 2009 Tentang Perlindungan Dan Pengelolaan Lingkungan Hidup akan tetapi sanksi pidana tersebut belum diterapkan sepenuhnya dilapangan terhadap pelaku tindak pidana pembakaran hutan seperti perusahaan. Apabila dilihat dari berita yang ditayangkan di televisi bahwa banyak kasus yang terungkap terkait dengan pembakaran hutan pelakunya hanya orang perorangan saja seperti kasus yang terjadi di Areal Konsesi PT. Reki Batanghari yang mana Kepolisian telah menetapkan 18 orang tersangka pelaku pembakaran hutan. ${ }^{18}$

Namun, apabila perusahaan yang melakukan pembakaran hutan tersebut maka jarang sekali kasus tersebut terungkap dan pelakunya dijatuhkan sanksi pidana sesuai dengan Pasal 108 Undang-Undang Nomor 32 Tahun 2009 Tentang Perlindungan Dan Pengelolaan Lingkungan Hidup. Dalam hal ini, terkait dengan pelaku tindak pidana pembakaran hutan yang dilakukan oleh perusahaan hanya dilakukan penyegelan saja. Hal yang demikian dapat dibuktikan dengan adanya berita yang menyatakan bahwa berdasarkan daftar perusahaan yang telah disegel hingga hari ini akibat kebakaran hutan dan lahan, PT ABT merupakan salah satu dari 42 konsesi yang telah disegel oleh Menteri Lingkungan Hidup dan Kehutanan (KLHK). ${ }^{19}$

Sementara itu, jika dilihat dari keberadaan Undang-Undang Nomor 32 Tahun 2009 Tentang Perlindungan Dan Pengelolaan Lingkungan Hidup tersebut bukan semata-mata hanya dijerat terhadap orang perorangan saja melainkan juga badan hukum atau perusahaan yang melakukan pelanggaran terhadap undang-undang tersebut termasuk juga perusahaan yang melakukan tindak pidana pembakaran hutan. Akan tetapi, pada kenyataannya walaupun perusahaan itu melakukan pembakaran hutan tetapi masih tetap saja perusahaan tersebut beroperasi dalam menjalankan usahanya. Hal yang demikian tentu sangat disayangkan mengingat dalam penegakan hukum sudah seharusnya badan usaha atau perusahaan tersebut harus dijerat dengan sanksi pidana sesuai dengan isi yang terdapat di dalam Undang-Undang Nomor 32 Tahun 2009 Tentang Perlindungan Dan Pengelolaan Lingkungan Hidup.

Selain itu, apabila dilihat dari aparat penegak hukum yang telah diatur dalam Undang-Undang Nomor 32 Tahun 2009 Tentang Perlindungan Dan Pengelolaan Lingkungan Hidup maka telah terdapat 2 penegak hukum. Hal ini dapat dilihat di dalam Pasal 94 ayat (1) yang berisikan bahwa selain penyidik pejabat polisi Negara Republik Indonesia, pejabat pegawai negeri sipil tertentu di lingkungan instansi pemerintah yang lingkup tugas dan tanggungjawabnya di bidang perlindungan dan pengelolaan lingkungan hidup diberi wewenang sebagai penyidik sebagaimana dimaksud dalam Hukum Acara Pidana untuk melakukan penyidikan tindak pidana lingkungan hidup.

Namun, walaupun telah ada 2 aparat penegak hukum yang diatur dalam Pasal 94 ayat (1) Undang-Undang Nomor 32 Tahun 2009 Tentang Perlindungan Dan Pengelolaan Lingkungan Hidup tersebut, pada kenyataannya masih banyak perusahaan yang belum terungkap terkait dengan tindak pidana pembakaran hutan. Hal ini telah menunjukkan bahwa belum efektif penegakan hukum terkait dengan tindak pidana pembakaran hutan terutama di Provinsi Jambi. Dengan demikian, sangat tidak wajar jika kasus pembakaran hutan itu tidak terungkap karena mengingat telah ada 2 penegak hukum yaitu penyidik kepolisian dan pejabat Pegawai Negeri Sipil. Untuk itu, sudah seharunya dilakukan pembenahan terhadap penegakan hukum guna untuk mencegah agar tidak terjadi lagi pembakaran hutan kembali di Provinsi Jambi.

\section{Faktor-Faktor Yang Mempengaruhi Penegakan Hukum Terhadap Pelaku Tindak Pidana Pembakaran Hutan Di Provinsi Jambi}

Setiap terjadinya suatu tindak pidana sudah seharusnya dilakukan penegakan hukum terhadap pelaku yang melakukan tindak pidana tersebut tanpa terkecuali termasuk juga pelaku tindak pidana pembakaran hutan di Provinsi Jambi. Penegakan hukum tersebut dilakukan agar tidak ada lagi pelaku pembakaran hutan karena akibat dari pembakaran hutan tersebut banyak merugikan masyarakat yang ada di Provinsi Jambi terutama masyarakat provinsi Jambi akan mengalami mata pedih dan sesak nafas dikarenakan tebal asap dari akibat pembakaran hutan tersebut. Tidak hanya itu saja, masyarakat Provinsi Jambi juga akan dirugikan dengan adanya asap karena bagi penumpang pesawat terbang tidak akan dapat melanjutkan penerbangannya dikarenakan kabut asap yang tebal menutupi pandangan pilot sehingga penerbangan dibatalkan dan masih banyak lagi kerugian yang akan dialami oleh masyarakat yang ada di Provinsi Jambi akibat pembakaran hutan tersebut.

Mengingat begitu besar bahaya yang ditimbulkan dari akibat pembakaran hutan tersebut maka sudah seharusnya dilakukan penegakan hukum terhadap pelaku tindak pidana pembakaran hutan. Penegakan hukum tersebut

18 https://www.tribunnews.com/regional/2019/09/22/18-orang-jadi-tersangka-kasus-pembakaran-hutan-areal-konsesi-ptreki-kabupaten-batanghari-jambi, diakses tanggal 10 Oktober 2019.

19 https://mediaindonesia.com/read/detail/259455-penegakan-hukum-pada-perusahaan-pembakar-lahan-telah-diterapkan, diakses tanggal 10 Oktober 2019. 
tidak hanya memberi efek jera terhadap pelaku tindak pidana pembakaran hutan itu sendiri, melainkan juga memberi contoh kepada masyarakat untuk tidak melakukan pembakaran hutan di Provinsi Jambi. Namun, di dalam melakukan penegakan hukum terhadap pelaku tindak pidana pembakaran hutan tersebut tidak semudah begitu saja, banyak faktorfaktor yang mempengaruhi penegakan hukum tersebut.

Adapun faktor yang mempengaruhi penegakan hukum tersebut yaitu berawal dari penegak hukumnya itu sendiri. Penegak hukum ini yang dapat melakukan penegakan hukum terhadap siapa saja yang melakukan pelanggaran aturan hukum baik melanggar aturan hukum umum berarti kitab undang-undang hukum pidana maupun aturan khusus seperti dalam hal ini Undang-Undang Nomor 32 Tahun 2009 Tentang Perlindungan Dan Pengelolaan Lingkungan Hidup. Dikatakan bahwa faktor yang mempengaruhi penegakan hukum adalah dari penegak hukumnya karena penegak hukum ini secara langsung maupun tidak langsung berkecimpung di dalam penegakan hukum itu sendiri. ${ }^{20}$ Apabila di dalam penegakan hukum tidak ada penegak hukum maka hukum tidak akan dapat ditegakkan di dalam masyarakat sehingga bagi yang melanggar aturan hukum tidak akan mendapat sanksi yang telah diatur dalam undangundang tersebut, termasuk dalam hal ini Undang-Undang Nomor 32 Tahun 2009 Tentang Perlindungan Dan Pengelolaan Lingkungan Hidup. Adapun celengan yang secara langsung berkecimpung di bidang penegakan hukum adalah mereka yang bertugas di bidang Kepolisian, kejaksaan, kepengacaraan, kenotariatan, pengadilan dan lembaga pemasyarakatan. ${ }^{21}$

Dalam hal ini, jika dilihat di dalam Undang-Undang Nomor 32 Tahun 2009 Tentang Perlindungan Dan Pengelolaan Lingkungan Hidup terdapat 2 penegak hukum antara lain penyidik pejabat polisi Negara Republik Indonesia, Pejabat Pegawai Negeri Sipil tertentu di lingkungan instansi pemerintah yang lingkup tugas dan tanggungjawabnya di bidang perlindungan dan pengelolaan lingkungan hidup. Ini berarti bahwa di dalam penegakan hukum terkait dengan pembakaran hutan telah ada dua penegak hukum yang memiliki kewenangan dalam pengelolaan lingkungan hidup sehingga kedua penegak hukum tersebut dapat melakukan penyelidikan terkait dengan kasus kebakaran hutan yang ada di Provinsi Jambi.

Walaupun telah terbentuk dua aparat penegak hukum yang bertanggungjawab di bidang perlindungan dan pengelolaan lingkungan hidup tersebut, akan tetapi dalam pengungkapan kasus tindak pidana pembakaran hutan yang dilakukan oleh perusahaan sulit untuk dibuktikan sehingga memerlukan waktu yang cukup lama dan akibat dari lamanya waktu penyelidikan tersebut maka perusahaan tersebut memiliki peluang besar untuk lepas dari jeratan sanksi pidana dikarenakan melebihi batas waktu dalam penyelidikan. Oleh karena itu, sumber daya manusia yang ada di penegak hukum harus ditingkatkan sehingga dalam mengungkapkan kasus tindak pidana pembakaran hutan, penegak hukum akan lebih cepat dalam menuntaskan kasus pembakaran hutan tersebut.

Untuk dapat mengungkapkan kasus pembakaran hutan dengan waktu yang cepat maka penegak hukumnya harus mempunyai skill atau kemampuan dalam hal pengelolaan lingkungan hidup dan pemahaman terhadap isi dari setiap undang-undang terkait dengan tindak pidana pembakaran hutan sehingga cepat dalam melakukan penangkapan terhadap pelaku tindak pidana pembakaran hutan di Provinsi Jambi.

Tidak hanya itu saja, sarana dan prasarana terkait dengan mengungkapkan suatu kasus termasuk kasus pembakaran hutan harus dipersiapkan juga di dalam penegakan hukum. Menurut Abintoro Prakoso, sarana atau fasilitas hukum antara lain mencakup sumber daya manusia yang berpendidikan dan terampil, organisasi yang baik, perkantoran dan peralatan pendukungnya yang lengkap dan sesuai dengan kebutuhan/perkembangan, dana dan tingkat kesejahteraan aparatnya yang cukup.22

Jadi, selain sumber daya manusia pada penegak hukum yang harus ditingkatkan, peralatan yang mendukung untuk mengungkapkan suatu tindak pidana pembakaran hutan juga harus digunakan sehingga aparat penegak hukum tidak menggunakan peralatan seadanya saja dalam mengungkapkan tindak pidana pembakaran hutan di Provinsi Jambi. Untuk itu, diperlukan peralatan peralatan pendukung yang canggih seperti alat yang dapat melihat titik api di setiap daerah yang ada di Provinsi Jambi karena alat yang di tersebut masih sulit untuk didapatkan oleh penegak hukum sehingga penegak hukum sulit untuk mencari titik api akibat pembakaran hutan tersebut.

Kemudian faktor-faktor yang mempengaruhi penegak hukum terhadap pelaku tindak pidana pembakaran hutan tersebut adalah pembuktian yang ada di dalam undang-undang tersebut karena pembuktian yang ada di Pasal 96 Undang-Undang Nomor 32 Tahun 2009 Tentang Perlindungan Dan Pengelolaan Lingkungan Hidup dirasakan terlalu banyaksehingga memerlukan waktu yang cukup lama dalam mengungkapkan kasus tindak pidana pembakaran hutan. Adapun pembuktian yang terdapat di Pasal 96 yaitu alat bukti yang sah dalam tuntutan tindak pidana lingkungan hidup terdiri atas :

a. Keterangan saksi.

b. Keterangan ahli.

${ }^{20}$ Soerjono Soekanto, Faktor-Faktor Yang Mempengaruhi Penegakan Hukum, (Jakarta : Rajawali Pers, 2014), halaman

19.

${ }^{21}$ Abintoro Prakoso, Sosiologi Hukum, (Yogyakarta : Laksbang Grafika, 2017), halaman 230.

${ }^{22} \mathrm{Ibid}$, halaman 223. 
c. Surat.

d. Petunjuk.

e. Keterangan terdakwa; dan/atau

f. Alat bukti lain, termasuk alat bukti yang diatur dalam peraturan perundang-undangan.

Apabila dilihat dari enam macam alat bukti untuk mengungkapkan suatu tindak pidana pembakaran hutan maka dirasakan sangat banyak dan harus memerlukan waktu yang cukup lama untuk memenuhi keenam alat bukti tersebut. Akibatnya apabila keenam alat bukti tersebut tidak cukup maka pelaku dapat saja dinyatakan tidak bersalah dan dibebaskan dari penjatuh an sanksi. Hal ini sesuai dengan isi Pasal 191 ayat (1) Kitab Undang-Undang Hukum Acara Pidana (KUHAP) dimana isi pasal tersebut berbunyi bahwa jika pengadilan berpendapat bahwa dari hasil pemeriksaan di sidang kesalahan terdakwa atas perbuatannya yang didakwakan kepadanya tidak terbukti secara sah dan meyakinkan, maka terdakwa diputus bebas. Oleh karena itu, dari alat bukti yang terdapat di Pasal 96 UndangUndang Nomor 32 Tahun 2009 Tentang Perlindungan Dan Pengelolaan Lingkungan Hidup sudah seharusnya dilakukan penyempitan terkait dengan jumlah alat bukti tersebut.

\section{Upaya Penegakan Hukum Yang Akan Datang Terhadap Pelaku Tindak Pidana Pembakaran Hutan Di Provinsi Jambi}

Di dalam melakukan penegakan hukum tentunya tidak semudah yang dipikirkan karena membutuhkan proses yang cukup lama untuk menjerat pelaku tindak pidana termasuk juga pelaku tindak pidana pembakaran hutan di Provinsi Jambi. Menurut Abintoro Prakoso, sejak hukum itu mengandung perintah dan paksaan, maka sejak itu membutuhkan bantuan untuk mewujudkan perintah tersebut. ${ }^{23}$ Dalam hal untuk mewujudkan perintah tersebut maka dibutuhkan penegak hukum untuk menjalankan perintah dan paksaan terhadap pelaku tindak pidana yang terdapat di dalam undang-undang tersebut, termasuk juga menjalankan isi Undang-Undang Nomor 32 Tahun 2009 Tentang Perlindungan Dan Pengelolaan Lingkungan Hidup terhadap pelaku pembakaran hutan yang terjadi di Provinsi Jambi.

Oleh karena itu, dibutuhkan penegak hukum yang mempunyai pendidikan yang lebih tinggi sehingga penegak hukum tersebut dapat memahami di setiap isi undang-undang sehingga penegak hukum tersebut dapat mengetahui apakah perbuatan tersebut termasuk dalam undang-undang atau tidak. Jika memang belum ada aturan hukum yang terkait dengan kejahatan tersebut maka aparat penegak hukum khususnya kepolisian harus melakukan koordinasi secara langsung kepada pemerintah khususnya kepada Dewan Perwakilan Rakyat sehingga dapat mengeluarkan aturan hukum dalam hal yang mendesak seperti Perpu.

Dengan adanya aturan hukum terkait dengan mengatur tindak pidana tersebut seperti dalam hal ini UndangUndang Nomor 32 Tahun 2009 Tentang Perlindungan Dan Pengelolaan Lingkungan Hidup maka penegak hukum dapat dengan mudah menjerat pelaku tindak pidana pembakaran hutan. Akan tetapi, yang menjadi permasalahan di dalam Undang-Undang Nomor 32 Tahun 2009 Tentang Perlindungan Dan Pengelolaan Lingkungan Hidup ini adalah terkait dengan masalah pembuktian yang terdapat di dalam Pasal 96 karena terlalu banyak alat bukti yang harus dipenuhi oleh aparat penegak hukum. Seharusnya di dalam Undang-Undang Nomor 32 Tahun 2009 Tentang Perlindungan Dan Pengelolaan Lingkungan Hidup tidak perlu terlalu banyak alat bukti yang harus dipenuhi oleh aparat penegak hukum karena mengingat waktu yang singkat di dalam membuktikan salah atau tidaknya pelaku tindak pidana pembakaran hutan tersebut.

Oleh karena itu, terkait pembuktian yang terdapat di dalam Pasal 96 tersebut harus dipersempit lagi jumlah alat bukti seperti keterangan ahli, bukti surat dan alat bukti lain, termasuk alat bukti yang diatur dalam peraturan perundang-undangan tidak perlu dimasukkan ke dalam Pasal 96 Undang-Undang Nomor 32 Tahun 2009 Tentang Perlindungan Dan Pengelolaan Lingkungan Hidup karena tindak pidana pembakaran hutan ini bukan seperti tindak pidana lain yang harus membutuhkan bukti surat sebab terjadinya tindak pidana pembakaran hutan tersebut tidak ada dibutuhkan surat untuk melakukan pembakaran hutan, berbeda dalam hal tindak pidana korupsi yang memang harus dibuktikan dengan adanya surat sebagai data otentik.

Selain itu juga, terkait pembuktian yang menggunakan keterangan ahli seharusnya digunakan pada saat proses persidangan bukan untuk pembuktian yang dilakukan oleh pihak kepolisian dan Pejabat Pegawai Negeri Sipil lingkungan. Jika keterangan ahli ini diharuskan di dalam pembuktian maka harus menunggu lagi kedatangan ahli untuk memberi keterangan tersebut sehingga membutuhkan waktu yang yang lama apabila ahli tersebut berasal dari luar Provinsi Jambi.

Kemudian terkait dengan alat bukti lain, termasuk alat bukti yang diatur dalam peraturan perundang-undangan jika dilihat dari penjelasan Pasal 96 Undang-Undang Nomor 32 Tahun 2009 Tentang Perlindungan Dan Pengelolaan Lingkungan Hidup yang berbunyi Yang dimaksud dengan alat bukti lain, meliputi informasi yang diucapkan, dikirimkan, diterima, atau disimpan secara elektronik, magnetik, optik, dan/atau yang serupa dengan itu, dan/atau alat bukti data, rekaman, atau informasi yang dapat dibaca, dilihat dan didengar yang dapat dikeluarkan dengan dan/atau

\footnotetext{
${ }^{23}$ Ibid, halaman 228 .
} 
tanpa bantuan suatu sarana, baik yang tertuang di atas kertas, benda fisik apapun selain kertas, atau kau yang terekam secara elektronik, tidak terbatas pada tulisan, suara atau gambar, peta, rancangan, foto atau sejenisnya, huruf, tanda, angka, simbol, atau perporasi yang memiliki makna atau yang dapat dipahami atau dibaca.

Jika dilihat dari penjelasan di atas maka alat bukti lain tersebut seharusnya tidak dimuatkan di dalam Pasal 96 Undang-Undang Nomor 32 Tahun 2009 Tentang Perlindungan Dan Pengelolaan Lingkungan Hidup sebab terlalu banyak syarat-syarat yang harus dipenuhi oleh aparat penegak hukum untuk menjerat pelaku tindak pidana pembakaran hutan. Dengan demikian, dalam hal pembuktian seharusnya alat bukti yang digunakan untuk mengungkapkan tindak pidana lingkungan hidup, dalam hal ini tindak pidana pembakaran hanya memerlukan tiga alat bukti saja yaitu keterangan saksi yang secara langsung melihat, mendengar dan mengalami di lapangan, petunjuk berupa barang bukti yang didapatkan di lapangan, rekaman suara, video, foto terkait dengan terjadinya tindak pidana pembakaran hutan dan keterangan ahli yaitu orang yang bersangkutan dalam hal ini mereka yang melakukan pembakaran hutan.

Tidak hanya pembuktian dan sumber daya manusia yang ada di penegak hukum saja yang menjadi faktor yang mempengaruhi penegakan hukum, masalah sarana prasarana atau fasilitas turut mempengaruhi penegakan hukum. Sarana prasarana atau fasilitas tersebut dalam hal ini alat yang mendukung harus sesuai dengan perkembangan kejahatan dan perkembangan zaman sehingga para penegak hukum untuk menegakkan hukum terhadap pelaku tindak pidana pembakaran hutan tidak hanya menggunakan peralatan seadanya saja, mereka harus dibekali juga peralatan yang memadai seperti GPS atau Radar yang dapat mengetahui titik api sehingga aparat penegak hukum langsung bergerak untuk melakukan penyelidikan guna mengungkapkan siapa pelaku yang melakukan pembakaran hutan tersebut.

\section{SIMPULAN}

1. Efektivitas penegakan hukum terhadap pelaku tindak pidana pembakaran hutan di Provinsi Jambi adalah belum efektif penegakan hukum terhadap pelaku tindak pidana pembakaran hutan di Provinsi Jambi karena penegak hukum dalam melakukan penegakan hukum masih tebang pilih terhadap pelaku pembakaran hutan seperti terhadap pelaku perorangan dijerat sanksi pidana, sedangkan terhadap perusahaan masih banyak perusahaan belum dijatuhkan sanksi pidana bahkan hanya PT. ABT disegel oleh Menteri Lingkungan Hidup dan Kehutanan (KLHK).

2. Faktor-faktor yang mempengaruhi penegakan hukum terhadap pelaku tindak pidana pembakaran hutan di Provinsi Jambi adalah skill atau kemampuan sumber daya manusia penegak hukum masih minim terhadap pemahaman terhadap tindak pidana lingkungan hidup, peralatan yang digunakan untuk mengungkapkan tindak pidana pembakaran hutan belum canggih dan masih terdapat banyak alat bukti yang harus dipenuhi penegak hukum dalam hal pembuktian.

3. Upaya penegakan hukum yang akan datang terhadap pelaku tindak pidana pembakaran hutan di Provinsi Jambi adalah skill atau kemampuan sumber daya manusia penegak hukum harus ditingkatkan lagi dengan cara mengikuti pendidikan yang lebih tinggi, peralatan yang digunakan harus mengikuti perkembangan zaman (canggih) seperti GPS atau Radar yang dapat mengetahui titik api dan pembuktian seharusnya alat bukti yang digunakan hanya tiga saja yaitu keterangan saksi, petunjuk dan keterangan ahli.

\section{DAFTAR PUSTAKA}

\section{Buku}

Abdoel Djamali, Pengantar hukum Indonesia, Jakarta : Rajawali Pers, 2014

Abintoro Prakoso, Kriminologi Dan Hukum Pidana, Yogyakarta : Laksbang Grafika, 2013

Abintoro Prakoso, Sosiologi Hukum, Yogyakarta : Laksbang Pressindo, 2017

Masrudi Muchtar, Abdul Khair Dan Noraida, Hukum Kesehatan Lingkungan (Kajian Teoritis Dan Perkembangan Pemikiran), Yogyakarta : Pustaka Baru Press, 2016

Nandang Sambas dan Ade Mahmud, Perkembangan Hukum Pidana Dan Asas-Asas Dalam RKUHP, Bandung : PT. Refika Aditama, 2019

Roni Wiyanto, Asas-Asas Hukum Pidana Indonesia, Bandung : CV. Mandar Maju Pres, 2012

Soerjono Soekanto, Faktor-Faktor Yang Mempengaruhi Penegakan Hukum, Jakarta : Rajawali Pers, 2012

\section{Peraturan Perundang-undangan}

Undang-Undang Nomor 32 Tahun 2009 Tentang Perlindungan Dan Pengelolaan Lingkungan Hidup

\section{Internet}

https://mediaindonesia.com/read/detail/259455-penegakan-hukum-pada-perusahaan-pembakar-lahan-telah-diterapkan 
https://www.cnnindonesia.com/nasional/20190821080552-20-423248/satu-perusahaan-perkebunan-di-jambi-disegelakibat-karhutla

https://www.liputan6.com/health/read/4070445/kualitas-udara-jambi-akibat-kabut-asap-saat-ini-lebih-buruk-dari-2015 https://www.tribunnews.com/regional/2019/09/22/18-orang-jadi-tersangka-kasus-pembakaran-hutan-areal-konsesi-ptreki-kabupaten-batanghari-jambi 